\title{
Analysis of the response of Saccharomyces cerevisiae cells to Kluyveromyces lactis toxin
}

\author{
ANDRew R. Butler, John H. White $\dagger$ and Michael J. R. StaRK* \\ Department of Biochemistry, The University, Dundee DD1 4HN, UK
}

(Received 31 December 1990; revised 25 March 1991; accepted 11 April 1991)

\begin{abstract}
The response of Saccharomyces cerevisiae cells to the toxin produced by certain strains of Kluyveromyces lactis was studied. The toxin caused an arrest of sensitive cells in the unbudded (G1) phase of the cell cycle, consistent with the accumulation of cells with an unreplicated (G1) content of DNA in treated populations. However, toxintreated cells were not proficient for mating. The effects of the toxin were dependent on its continuous presence for over an hour and removal of cells into fresh medium at earlier times prevented inhibition. Following toxin treatment, cells increased in volume and continued to synthesize protein and RNA, suggesting that they were able to continue growth in the absence of division. However, several lines of evidence suggested that the toxin does not simply block proliferation in G1, but that another continuous or post-G1 event is also affected. Possible models to explain these observations are discussed.
\end{abstract}

\section{Introduction}

Certain 'killer' strains of the yeast Kluyveromyces lactis secrete a heterotrimeric protein toxin which is inhibitory to a range of sensitive yeasts including Saccharomyces cerevisiae (reviewed by Stark et al., 1990). The toxin causes sensitive yeasts to arrest proliferation as unbudded cells, suggesting that it blocks completion of the Gl phase of the cell division cycle. Initial work suggested that this block was mediated by direct inhibition of the adenylyl cyclase of sensitive cells (Sugisaki et al., 1983). However, we have shown recently that the toxin cannot inhibit proliferation in this manner (White et al., 1989), leaving its mode of action unresolved. We have therefore begun a combined genetic and biochemical approach aimed at understanding the mode of action of the toxin, hoping to identify novel cell cycle regulatory events required for completion of $\mathrm{Gl}$. Although the toxin consists of three subunits, inhibitory activity resides solely in the $\gamma$ subunit (Tokunaga et al., 1989; Butler et al., $1991 b$ ); however, the other two subunits are required for inhibition of sensitive cells by the toxin, and the $\alpha$ subunit has an essential chitinase activity (Butler $e t$ al., $1991 a$ ). The function of the $\beta$ subunit is currently unknown.

$\dagger$ Present address: Institute of Cellular \& Molecular Biology, King's Buildings, Mayfield Road, Edinburgh EH9 3JR.

Abbreviations: Pip- $\mathrm{HCl}, 25 \mathrm{~mm}$-piperazine/ $\mathrm{HCl} ; \mathrm{MIC}$, minimum inhibitory concentration.
Here we report a detailed analysis of the effects of the toxin on sensitive yeast cells, and demonstrate that toxinarrested cells have a pre-replication content of DNA, providing stronger evidence for a G1 block, although, unlike mating pheromone-arrested cells, toxin-arrested cells are not proficient for mating. Several lines of evidence suggest that the toxin may promote differential inhibition of a second cellular process which is not G1specific.

\section{Methods}

General methods. All strains used in this work, including our standard toxin-sensitive strain LL20, are described in Table 1. Growth media were as described by Sherman et al. (1986). Strains in liquid culture were grown in YPD medium at $28^{\circ} \mathrm{C}$ with orbital shaking at 200 r.p.m. Cell density and percent budding were monitored by fixing small culture samples in $3.7 \%(\mathrm{v} / \mathrm{v})$ formaldehyde solution and gently sonicating to disaggregate clumps. Fixed cells were viewed in a haemocytometer at $400 \times$ magnification, using phase contrast, and at least 200 cells observed to derive the data. Cell viability in cultures was assessed by plating suitable dilutions on YPD plates at $28^{\circ} \mathrm{C}$. Where cell volume was studied, this was estimated from measurements of the long and short axes of individual cells from photomicrographs (printed at $\sim 4000 \times$ magnification) treating cells as prolate ellipsoid in shape. For budded cells, the volume of the mother and daughter (bud) portions was estimated separately.

Toxin purification. Cultures $(251)$ of the $K$. lactis toxin-producing strain IFO1 267 were grown in YPD medium containing $50 \mathrm{~mm}$-sodium phosphate buffer (pH 6.0), at $28^{\circ} \mathrm{C}$, in a New Brunswick fermenter, with agitation (200 r.p.m.) and forced aeration $\left(61 \mathrm{~min}^{-1}\right)$. When the 
Table 1. Saccharomyces cerevisiae strains used

\begin{tabular}{lll}
\hline \hline Strain & \multicolumn{1}{c}{ Genotype } & \multicolumn{1}{c}{ Source } \\
\hline ARB1 & a leu2-3 leu2-112 his3-11 his3-15 ktil (K. lactis-toxin-resistant) & A.R.B. \& M. J.R.S. \\
ARB15 & a leu2-3 leu2-112 his3-11 his3-15 KTI5 (K. lactis-toxin-resistant) & A.R.B. \& M.J.R.S. \\
KY117 & a ura3-52 trp1- 1 lys2-801 lam ade2-101 his3- $\Delta 200$ GAL & Dr M. A. Romanos, Wellcome Foundation \\
LL20 & a leu2-3 leu2-112 his3-11 his3-15 & NCYC* 1445 \\
RC1670 & a sst1-3 ura3-52 leu2-3 leu2-112 his3 his4 his6 cyh2 canl & Chan \& Otte (1982) \\
\hline \hline
\end{tabular}

* National Collection of Yeast Cultures, AFRC Institute of Food Research, Colney Lane, Norwich, UK.

culture reached $5 \times 10^{8}$ cells $\mathrm{ml}^{-1}$, the cells were removed using a Millipore Pellicon cassette filtration system (HVLP $0.45 \mu \mathrm{m}$ filter) and the extracellular proteins concentrated to $\sim 800 \mathrm{ml}$ by ultrafiltration using the same apparatus (PTHK filter; $M_{\mathrm{r}}$ cutoff $\sim 100 \mathrm{kDa}$ ), flushing out the filter with $100 \mathrm{ml} 50 \mathrm{~mm}$-phosphate buffer (pH 6.0). Ammonium sulphate was slowly added to $700 \mathrm{~g}^{-1}$, and the solution was stirred gently overnight. After clarification at $38000 \mathrm{~g}$ for $20 \mathrm{~min}$, the pellet was resuspended in $25 \mathrm{ml} 25 \mathrm{~mm}$-piperazine $/ \mathrm{HCl}(\mathrm{pH} \mathrm{6.0)}$ ) and dialysed extensively against the same buffer $(\mathrm{Pip}-\mathrm{HCl})$ at $4{ }^{\circ} \mathrm{C}$. This step was repeated using $260 \mathrm{~g} \mathrm{l}^{-1}$ ammonium sulphate, but resuspending the pellet in 2-4 ml Pip- $\mathrm{HCl}$. After dialysis as above, this sample was eluted over a Pharmacia C16/70 column of Biogel P-200 in Pip- $\mathrm{HCl}$, collecting $4 \mathrm{ml}$ fractions and locating the toxin (which elutes at the void volume) by SDS-PAGE analysis of small samples of each. Finally, the peak fractions were subjected to Chromatofocusing using a Mono $\mathrm{P}$ HR5/20 column (Pharmacia LKB) equilibrated with Pip- $\mathrm{HCl}$ and developing the column with $25 \mathrm{ml} 10 \%$ Polybuffer 74 (pH 3.5), collecting $0.5 \mathrm{ml}$ fractions. The toxin (which elutes at $\sim \mathrm{pH} 4.2$ in $1-2$ fractions) was located as above, and Polybuffer was removed from the pooled fractions by diafiltration with $50 \mathrm{~mm}$-phosphate buffer ( $\mathrm{pH} 6.0$ ) at $4{ }^{\circ} \mathrm{C}$, using Amicon CF 25 ultrafiltration cones so as to dilute small molecules by $>5000$-fold. After supplementing the toxin with 1.5 vols $50 \%$ glycerol containing $50 \mathrm{~mm}$-phosphate buffer $(\mathrm{pH} \mathrm{6.0)}$ ), toxin was assayed for protein content (Bradford, 1976) and stored at $-20^{\circ} \mathrm{C}$. Purity (assessed by SDS-PAGE) was always $>98 \%$.

Microtitre well assay of toxin activity. Measurement of toxin potency was based on the method of Romanos \& Boyd (1988) except that 2- or 5fold serial dilutions of toxin samples were prepared in YPD medium and duplicate $20 \mu \mathrm{l}$ samples of each added to $180 \mu$ l sensitive cells $\left(5.55 \times 10^{6}\right.$ cells $\mathrm{ml}^{-1}$ in YPD) in the wells of a microtitre plate. After growth at $28^{\circ} \mathrm{C}$ for $20 \mathrm{~h}$, each sample was diluted into $1.8 \mathrm{ml}$ water and the $\mathrm{OD}_{600}$ determined. Means of each set of duplicates were expressed as a percentage of the $\mathrm{OD}_{600}$ attained by control wells lacking toxin. To compare different toxin samples, such data were used to derive the minimum inhibitory concentration (MIC) or ID $_{100}$ value by extending the linear, sloping portion of the curve thus obtained to the X-axis (Fig. $1 a$ ). For given strains of $S$. cerevisiae, the $\mathrm{ID}_{100}$ value thus obtained was very reproducible. For most strains examined, the $\mathrm{ID}_{100}$ value proved to be the same as the minimum inhibitory concentration of toxin determined using shaken flask cultures.

Assay of macromolecular biosynthesis by yeast cultures. Cultures $(10 \mathrm{ml})$ of $\mathrm{RC} 1670$ were grown in SD medium containing $0.4 \%$ yeast extract until they reached $3 \times 10^{6} \mathrm{cells} \mathrm{ml}^{-1}$ and then supplemented with $30 \mu \mathrm{Ci}\left[5,6^{-3} \mathrm{H}\right]$ uracil $\left(10 \mathrm{Ci} \mathrm{mmol}^{-1}\right)$ and $4 \mu \mathrm{Ci}\left[{ }^{14} \mathrm{C}\right]$ protein hydrolysate $\left(50 \mathrm{mCi} \mathrm{mgatom}^{-1}\right)$. After $30 \mathrm{~min}$ further growth, some cultures were further supplemented with either purified $K$. lactis toxin at its minimal inhibitory concentration (ID $\left.{ }_{100}\right)$ or with $\alpha$-factor $(0.3 \mu \mathrm{g}$ $\left.\mathrm{ml}^{-1}\right)$. Duplicate samples $(400 \mu \mathrm{l})$ were taken at intervals and delivered into $4 \mathrm{ml}$ cold $10 \%(\mathrm{w} / \mathrm{v})$ trichloroacetic acid (TCA). Incorporation into protein was determined by measuring TCA-precipitable ${ }^{14} \mathrm{C}$ radioactivity after heating one set of samples to $100^{\circ} \mathrm{C}$ for $30 \mathrm{~min}$, while RNA synthesis was estimated as cold-TCA-precipitable ${ }^{3} \mathrm{H}$ radioactivity in the second sample. Incorporation was normalized to culture $\mathrm{OD}_{600}$ in order to express incorporation in terms of cell mass. In control experiments, sampling error was shown to be less than $\pm 10 \%$.

Flow cytometric determination of cellular DNA content. Samples of cells from control and toxin-treated cultures were fixed in $70 \%(\mathrm{v} / \mathrm{v})$ ethanol and stored at $4{ }^{\circ} \mathrm{C}$. Portions of each sample (containing $\sim 5 \times 10^{7}$ cells) were washed once with $1 \mathrm{ml} 50 \mathrm{~mm}$-sodium citrate solution and then resuspended in $1 \mathrm{ml}$ of the same solution containing $1 \mathrm{mg} \mathrm{ml}^{-1}$ boiled RNase A and $20 \mu \mathrm{g} \mathrm{ml}^{-1}$ propidium iodide. After $3 \mathrm{~h}$ at $37^{\circ} \mathrm{C}$ in the dark, each sample was analysed using a BectonDickinson fluorescence-activated cell sorter (FACS). The FACS machine contained a $15 \mathrm{~mW}$ laser which provided an excitation wavelength of $488 \mathrm{~nm}$. Fluorescence was measured at $585 \mathrm{~nm}$. Data were collected on a linear scale using 10000 cells per sample. Under these conditions, fluorescence is considered to be proportional to DNA content (Hutter \& Eipel, 1979).

Mating competence. A KY117 culture was grown at $28^{\circ} \mathrm{C}$ in YPD medium until the cell density reached $3 \times 10^{6} \mathrm{ml}^{-1}$. Purified $\mathrm{K}$. lactis toxin $\left(5 \mathrm{mg} \mathrm{l}^{-1}\right)$ was then added to arrest proliferation. After $6 \mathrm{~h}$, quantitative mating assays were performed essentially according to Dutcher \& Hartwell (1982). Briefly, $1 \mathrm{ml}$ samples $\left(10^{6}\right.$ cells) of the toxin-treated culture were mixed with similar samples of cells of the opposite mating type (taken from exponentially growing cultures) and filtered through Millipore $0 \cdot 22 \mu \mathrm{m}$ nitrocellulose filters. Filters were placed on YPD agar with or without $1.5 \mathrm{ml}$ crude $K$. lactis toxin (equivalent to $25 \mathrm{ml} \mathrm{K}$. lactis killer strain culture supernatant) at $28^{\circ} \mathrm{C}$ for $5 \mathrm{~h}$, after which time the cells were resuspended in $1 \mathrm{M}$-sorbitol, and sonicated briefly before plating under conditions which selected for diploid cells resulting from conjugation.

\section{Results}

\section{pH optimum and thermal stability of the toxin}

Before commencing studies using purified $K$. lactis toxin, we determined the optimal conditions for its activity against sensitive $S$. cerevisiae cells in liquid culture by examining the response of our standard sensitive strain (LL20) to toxin in YPD medium over a range of $\mathrm{pH}$ conditions (3.0 to 8.0) where it was capable of growth at or near the normal rate observed in unbuffered medium. Fig. $1 b$ shows that the toxin is only particularly active between $\mathrm{pH} 6.5$ and 8 , with a sharp optimum around 

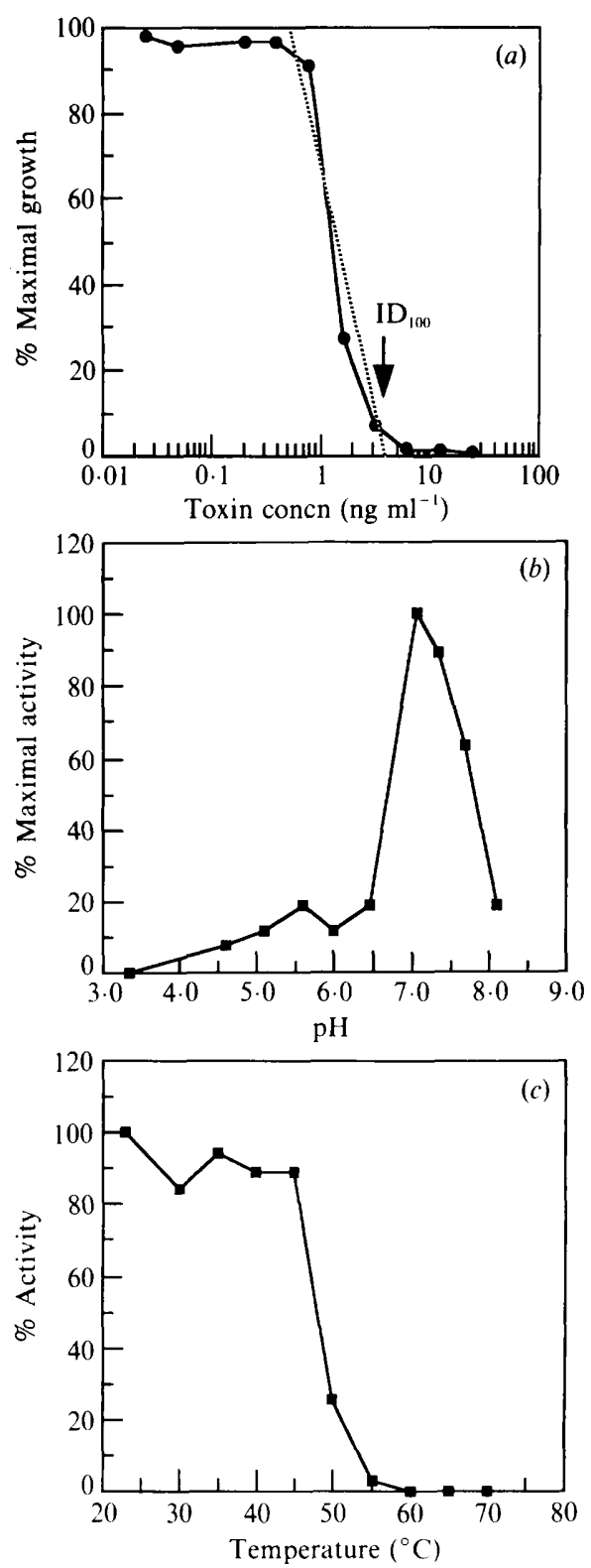

Fig. 1. pH optimum and thermal stability of $K$. lactis toxin. (a) Representative data showing the response of strain LL20 to $K$. lactis toxin in the standard microtitre well assay (see Methods) are presented. Each point is the mean of duplicate determinations (see Methods) which showed less than $5 \%$ variation. For a given strain, the minimum inhibitory concentration (ID 100 ) of toxin was defined by the point of intercept of the sloping portion of the plot with the X-axis $(\downarrow)$. (b) Representative results showing the $\mathrm{pH}$ dependence of toxin activity. The ID $_{100}$ of toxin against LL20 cells in YPD medium buffered at various $\mathrm{pH}$ values with $50 \mathrm{~mm}$-sodium phosphate was determined by microtitre well assay (making serial dilutions of the toxin in the buffered medium). The results were expressed as activity relative to that observed at $\mathrm{pH} 7.0$ (the optimal $\mathrm{pH}$ ) using the formula $100 \times\left[\operatorname{ID}_{100}(\mathrm{pH} 7) \div \mathrm{ID}_{100}(\mathrm{pH} \mathrm{x})\right] .(\mathrm{c})$ Representative data showing the thermal inactivation of $K$. lactis toxin. Toxin was held at various temperatures for $20 \mathrm{~min}$, cooled on ice and then assayed for activity against LL20 as in $(a)$. Percentage activity was calculated from the apparent $\mathrm{ID}_{100}$ values as in $(b)$, except that values were expressed in terms of the activity of an untreated toxin sample.
$\mathrm{pH}$ 6.8-7.0 (the $\mathrm{pH}$ of unbuffered YPD medium). Previous work using a different, less sensitive assay gave similar results, except that the $\mathrm{pH}$ optimum was much less sharp (Sugisaki et al., 1984). In all subsequent experiments, we therefore used unbuffered YPD as the growth medium of choice for testing the response to toxin. Despite not being deliberately buffered, the $\mathrm{pH}$ of YPD medium was quite stable during the exponential growth of cells and did not change significantly during any of the experiments reported here.

Comparison of the toxin-sensitivity of a large number of different strains in our standard microtitre well assay generally showed variations of around 5-fold in the toxin concentration required to inhibit cell growth, although a small number of strains were 25 to 50 -fold less sensitive. This can be compared with the response of spontaneously-arising toxin-resistant derivatives of $S$. cerevisiae LL20 which are essentially refractory to the toxin (Butler et al., $1991 \mathrm{~b}$ ). Various strains with mutations in the mating pheromone receptors (ste2, ste3), the mating response pathway (ste4), vacuolar biogenesis (vpll/vpt26, end1/vpt 11: Rothman \& Stevens, 1986; Banta et al., 1988; Robinson et al., 1988) or vacuolar protein targeting (vpl3/vpt8, vpl8/vptl7: ibid) or multiply vacuolar proteasedeficient strains (pral prb1 prcl cps1: Achstetter et al., 1984) did not show any significant resistance to the toxin.

We next examined the thermal stability of the toxin by treating small samples at temperatures between $23^{\circ} \mathrm{C}$ and $70^{\circ} \mathrm{C}$ for $20 \mathrm{~min}$, followed by assay of their potency. This clearly indicated that the toxin was completely stable at temperatures up to $50^{\circ} \mathrm{C}$ (Figure $1 c$ ), while further work (not shown) indicated a half-life of $10 \mathrm{~min}$ at $50{ }^{\circ} \mathrm{C}$.

Toxin promotes a time-dependent loss of viability in sensitive cells

We have previously shown that the toxin causes sensitive $S$. cerevisiae cells to arrest irreversibly in the unbudded (G1) phase of the cell cycle (White et al., 1989). The irreversibility of the arrest is manifest as a loss of colonyforming ability of toxin-treated cultures when subsequently plated out on YPD medium. We therefore examined the time-dependence of toxin action by asking whether toxin-treated cells could be rescued by removing them to prewarmed, toxin-free YPD medium at progressively longer times following treatment. Fig. 2 shows that the effect of the toxin on cell viability is strictly timedependent; toxin must be present for at least $90 \mathrm{~min}$ for the majority of cells to show irreversible arrest of proliferation. However, viability continued to decline on longer treatment with toxin even after proliferation had ceased (Fig. 2b). This suggests that the effects of the 

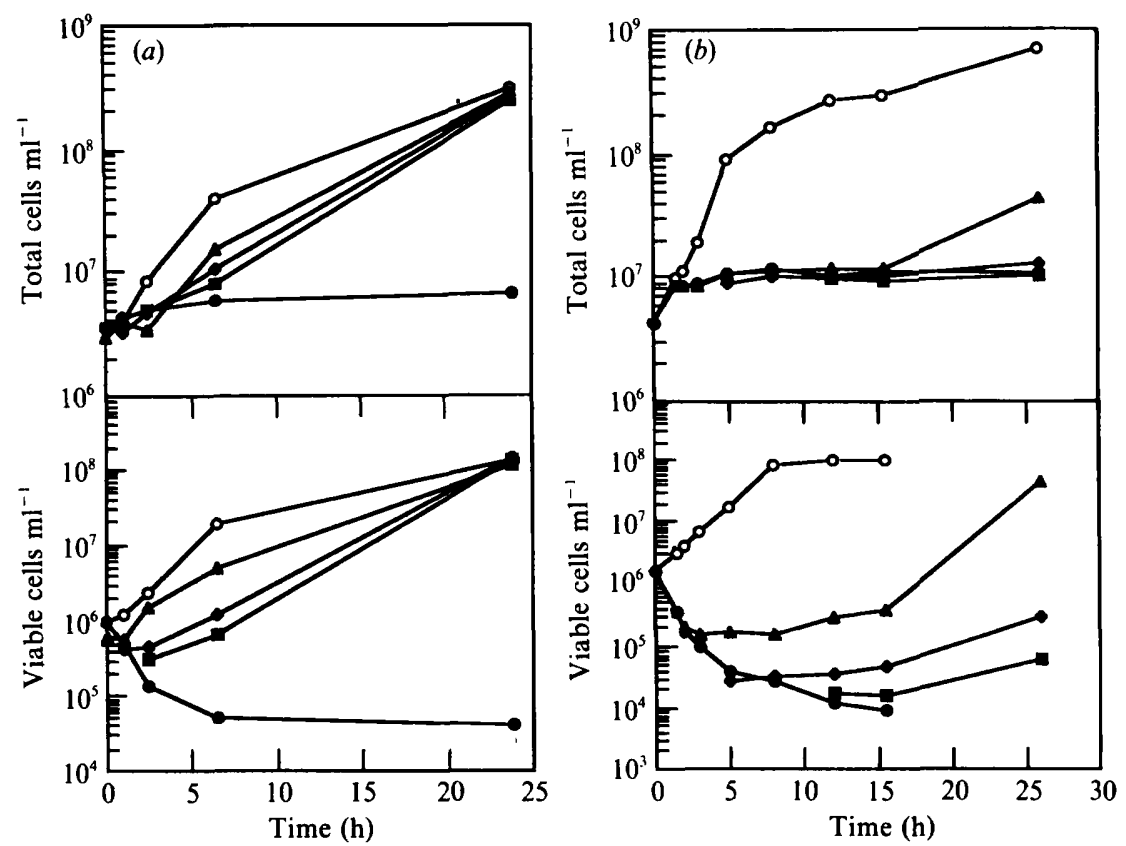

Fig. 2. Toxin promotes a time-dependent loss of viability in sensitive cells. An overnight culture of LL20 was subcultured into fresh YPD medium at $10^{6}$ cells ml-1 and shaken at $28^{\circ} \mathrm{C}$. When the cell density reached $3 \times 10^{6} \mathrm{cells} \mathrm{ml}^{-1}$ (time zero), a sample (20 ml) was removed to a fresh flask to act as an untreated control $(O)$ and purified $K$. lactis toxin $\left(5 \mathrm{ng} \mathrm{ml}^{-1}\right)$ added to the remainder $(O)$. At given times, $20 \mathrm{ml}$ aliquots were removed and the cells collected by centrifugation $(3000 \mathrm{~g}, 5 \mathrm{~min})$, then washed free of toxin by resuspension in an equal volume of $0.1 \mathrm{M}-2$-mercaptoethanol followed by harvesting as before. Cells were finally resuspended in $20 \mathrm{ml}$ YPD medium and incubation continued as above. Total cells $\mathrm{ml}^{-1}$ and viable cells $\mathrm{ml}^{-1}$ were monitored throughout the experiment for each culture. Two separate experiments are shown. In $(a)$, samples of cells were washed free of toxin immediately $(\Delta), 30(\Delta)$ and $60 \mathrm{~min}(\boldsymbol{\square})$ following toxin addition whereas in $(b)$ samples were removed after $90(\Delta), 270(\diamond)$ and $540 \mathrm{~min}(\square)$.

toxin on proliferation and cell viability may occur by different mechanisms.

\section{The synchrony of $G 1$ arrest by toxin is dose-dependent}

When sensitive yeast cells are treated with the ID $_{100}$ of $K$. lactis toxin, a clear arrest as unbudded cells is seen (White et al., 1989). For strain LL20, after 10-20 h of toxin treatment, the proportion of budded cells in the population has typically fallen from around $50 \%$ to about $10 \%$ (White et al., 1989; see Fig. 3c). However, when cells were treated with higher levels of the toxin, inhibition led to a noticeably less synchronous arrest of proliferation, with $20-30 \%$ budded cells in the treated population. We therefore conclude that while toxin arrests cells synchronously in G1 at its MIC, at higher concentrations this synchrony is to some extent lost. This is accompanied by a more rapid and much greater fall in viability of the treated population (Fig. $3 b$ ). One possible explanation for this effect is that the toxin exerts differential effects on G1-specific and continuous (or later, stage-specific) processes within the cell, the former being more sensitive than the latter. Alternatively, the toxin may target a single cellular process which, when partially blocked, results in a G1 arrest but which when more strongly inhibited leads to cessation of division at several stages within the cell cycle.

\section{Toxin treatment leads to an accumulation of cells with unreplicated DNA}

The fact that toxin-treated cells arrest in the unbudded state is indicative that they are blocked in the G1 phase of the cell cycle. However, a more stringent criterion would be to demonstrate that they contain unreplicated DNA. We therefore examined cells from toxin-treated and control cultures by propidium-iodide-staining of fixed samples and measurement of fluorescence (proportional to DNA content) using a fluorescence activated cell sorter. Fig. $4 a$ shows that the control cells fell into two distinct populations of approximately equal size when separated on this basis, corresponding to pre-S phase cells ( $1 \mathrm{n}$ DNA content) and cells in or beyond $S$ phase (1-2n DNA content). Following toxin treatment, the pre-S phase peak increased greatly at the expense of the latter (Fig. $4 b$ ). In fact, the $2 \mathrm{n}$ peak was no longer discernible as a separate population in the treated cultures. We therefore conclude the toxin treatment leads 


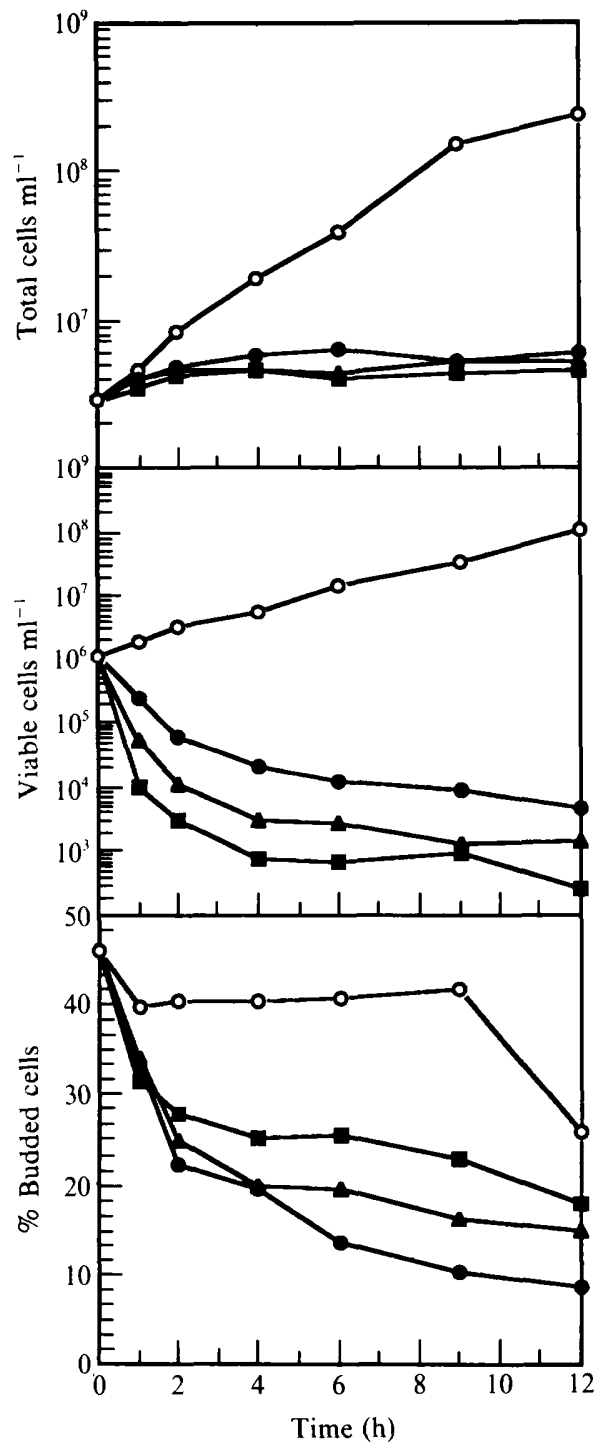

Fig. 3. Effect of $K$. lactis toxin concentration on the synchrony of arrest in G1. An overnight culture of LL20 was subcultured into $100 \mathrm{ml} \mathrm{YPD}$ medium at $10^{6}$ cells $\mathrm{ml}^{-1}$ and shaken at $28^{\circ} \mathrm{C}$. When the cell density reached $3 \times 10^{6}$ cells $\mathrm{ml}^{-1}$ (time zero), four $20 \mathrm{ml}$ samples were taken into prewarmed flasks and purified $K$. lactis toxin added as indicated below. Total cells $\mathrm{ml}^{-1}$, viable cells $\mathrm{ml}^{-1}$ and the percentage of budded cells were monitored throughout the experiment for each culture. Similar results were obtained in a second experiment using glycerol as carbon source. $O$, No toxin; $-5 \mathrm{ng} \mathrm{ml}^{-1} ; \Delta, 50 \mathrm{ng} \mathrm{ml}^{-1} ; \square$, $250 \mathrm{ng} \mathrm{ml}^{-1}$.

to the accumulation of cells which have not replicated their DNA. Taken together with their unbudded morphology, this clearly indicates that they become blocked in the G1 phase of the cell cycle.

\section{Cells arrested in $S$-phase can progress to $G 1$ in the presence of toxin}

Since the toxin is an irreversible inhibitor of $S$. cerevisiae proliferation, it is therefore impossible to map its

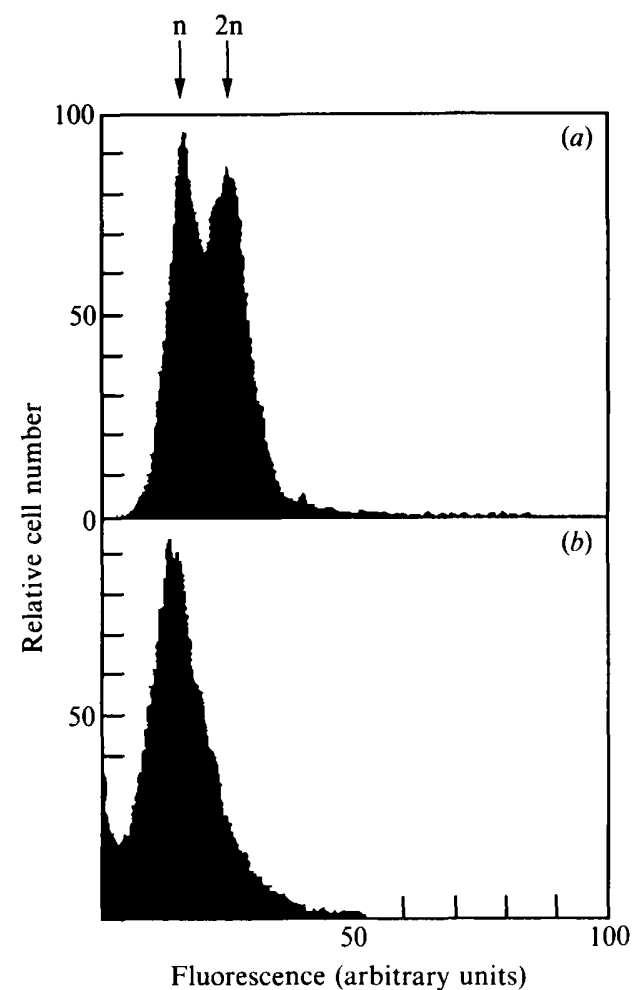

Fig. 4. DNA content of toxin-arrested cells. FACS analysis of control and toxin-treated LL20 cells ( $9 \mathrm{~h}$ after toxin addition) was performed to analyse their DNA content. In the control, two peaks (corresponding to in and 2n DNA content) were seen as expected. In the toxin-treated sample, the percentage of budded cells fell from $\sim 50 \%$ to $9 \%$ and the fluorescence peak corresponding to a 2 n DNA content essentially disappeared.

'execution point' in the cell cycle by the reciprocal shift method (Hereford \& Hartwell, 1974). However, if the toxin inhibits an event which normally occurs in Gl, then cells arrested after this event should be able to progress through the cell cycle in the presence of toxin until they reach $\mathrm{Gl}$. We therefore tested this hypothesis by blocking cells in S-phase with hydroxyurea and, having then added an inhibitory level of toxin concurrently for $2 \mathrm{~h}$, asked what happened to the cells when the hydroxyurea was removed in the continued presence of toxin. Fig. 5 shows that cells rapidly arrested in the budded portion of the cell cycle on addition of hydroxyurea, consistent with its known mode of action as an S-phase blocking agent (Slater, 1983) and shown by the jump in the proportion of budded cells. On removal of the inhibitor, cell proliferation recommenced at the original rate within $1 \mathrm{~h}$, and the proportion of budded cells fell back to the level seen in control cultures. However, if $K$. lactis toxin was added to the S-phasearrested cells for $2 \mathrm{~h}$ prior to hydroxyurea removal, in the continued presence of toxin the proportion of budded cells fell dramatically as the total number of cells in the 


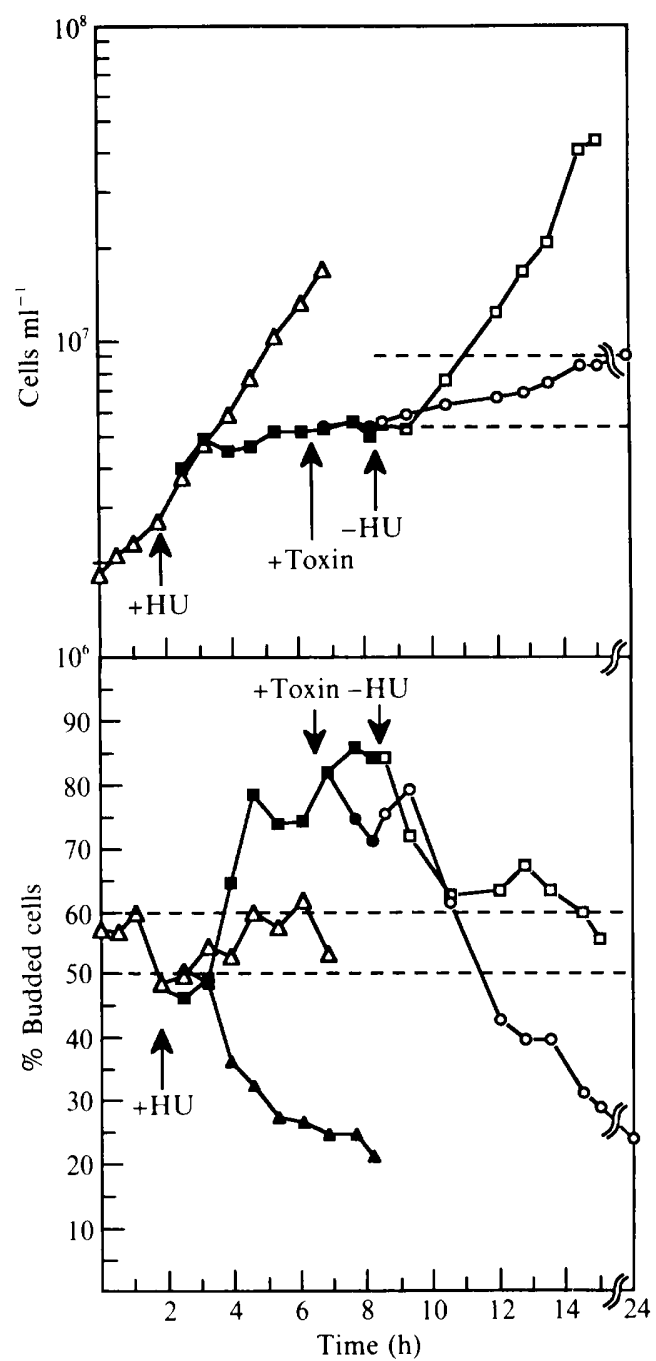

Fig. 5. Progression of cells from S-phase to G1 in the presence of $K$. lactis toxin. An overnight culture of LL20 was subcultured into $72 \mathrm{ml}$ YPD medium at $10^{\circ}$ cells $\mathrm{ml}^{-1}$ and was shaken at $28^{\circ} \mathrm{C}(\triangle)$. When the cell density reached $3 \times 10^{6}$ cells $\mathrm{ml}^{-1}$, a sample $(40 \mathrm{ml})$ was removed into a prewarmed flask containing $0.608 \mathrm{~g}$ hydroxyurea $(\mathrm{HU})(\boldsymbol{D})$ and a second sample $(10 \mathrm{ml})$ similarly removed and supplemented with $20 \mathrm{ng} \mathrm{m}^{-1} \mathrm{~K}$. lactis toxin $(\mathbf{\Delta})$. When the HU-treated cells were fully arrested in S-phase, a sample $(10 \mathrm{ml})$ was removed as above and supplemented with $20 \mathrm{ng} \mathrm{m}^{-1} \mathrm{~K}$. lactis toxin $(\mathbf{O})$. After $2 \mathrm{~h}$, the HUtreated culture was harvested and washed free of $\mathrm{HU}$ by centrifugation and resuspension in an equal volume of fresh, prewarmed YPD medium $(\square)$. The toxin-treated sample of the HU culture $(\boldsymbol{\Delta})$ was similarly washed free of $\mathrm{HU}$, but was grown in the continued presence of $20 \mathrm{ng} \mathrm{ml}^{-1} \mathrm{~K}$. lactis toxin $(O)$. Total cells $\mathrm{ml}^{-1}$ and the percentage of budded cells were monitored throughout the experiment for each culture sample. Dotted lines indicate the increase in cell numbers of the toxin-treated culture on release from HU arrest (top panel) and the range of values for percent budded cells normally observed in exponentially growing cultures of LL20 (lower panel). The data were confirmed in a second experiment (not shown).

population increased, indicating that the majority of Sphase cells had divided once following hydroxyurea release. We therefore conclude that cells arrested in S-

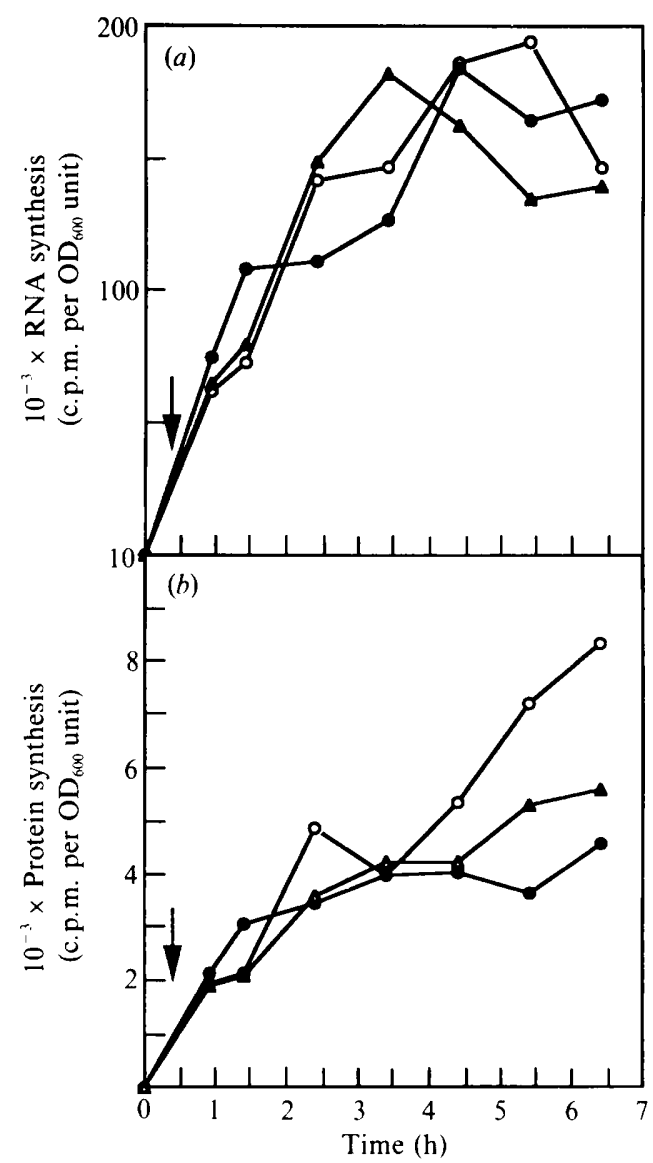

Fig. 6. Effect of $K$. lactis toxin on macromolecular biosynthesis. Incorporation of radiolabelled precursors into RNA $(a)$ and protein $(b)$ in $\mathrm{RC} 1670$ was measured, and expressed in terms of culture $\mathrm{OD}_{600}$ to correct for inhibition of cell division in the treated cultures (see Methods). Representative data from one of two experiments are presented. In each case, cultures were labelled for $25 \mathrm{~min}$ prior to addition of inhibitors in order to equilibrate intracellular pools. Similar results for the effects of toxin were obtained using several other strains (including LL20). $\bigcirc$, Untreated; $\boldsymbol{O}$, plus $K$. lactis toxin; $\hat{\Lambda}$, plus $\alpha$ factor.

phase can progress through the cell cycle to Gl in the presence of toxin, arguing that the toxin is a stagespecific inhibitor whose execution point precedes $\mathrm{S}$ phase. However, recovery of the cells in the presence of toxin is rather slow compared to that seen in its absence (Fig. 5). This suggests that the toxin affects a process (continuous or stage-specific) which follows S-phase, but which is perhaps only partially blocked under these conditions. Thus as cells slowly 'escape' this putative second block they can cycle round to Gl where they cease proliferation.

\section{Effect of toxin on macromolecular biosynthesis}

We next examined the effect of toxin on the synthesis of protein and RNA by sensitive cells by measuring the 
incorporation of radiolabelled precursors. Since toxin arrests cell proliferation, incorporation of radiolabel into protein and RNA was expressed in terms of the culture $\mathrm{OD}_{600}$ in order to relate incorporation to cell mass and thus enable meaningful comparison of toxin-treated and control cultures. Fig. 6 shows that, relative to control cultures, incorporation of precursors into protein was reduced by $\sim 30 \%$ after $4-6 \mathrm{~h}$ toxin inhibition, whereas there was little significant effect on RNA synthesis. Given that the toxin exhibits a lag period of around 60 $90 \mathrm{~min}$ (above), the effect on protein synthesis might be considered more significant. However, treatment of identical cultures with $\alpha$-factor gave a similar result (i.e. $\sim 30 \%$ inhibition after $6 \mathrm{~h}$ ). In contrast, cycloheximide used at a concentration which caused cells to cease growth and division with similar kinetics to toxin (i.e. over 1-1.5 doubling times) completely abolished incorporation into protein at all time points in similar experiments (not shown). Similar results for the effect of toxin on RNA and protein biosynthesis were obtained using several different strains including LL20 (our standard sensitive strain). We therefore conclude that while there is significant inhibition of macromolecular synthesis in toxin-treated cells, this is probably not a primary effect of the toxin and is similar to that seen when cells are arrested in Gl by other, better characterized means.

\section{Effect of toxin on cell volume and mating competence}

Mating pheromone and many $c d c$ mutations which cause G1 arrest in S. cerevisiae block proliferation at Start, the first genetically definable point in the cell cycle which represents the commitment point to a new division (Wheals, 1987). Start blocks classically fall into two categories: in a Class I arrest (e.g. in a $c d c 28$ mutant or following pheromone treatment), growth continues and cells remain mating competent, but in a Class II arrest (e.g. caused by $c d c 25, c d c 35$ or other adenylyl cyclase pathway 'down' mutations) growth is inhibited as well as division, and cells are not proficient in mating (Wheals, 1987). It was therefore of interest to examine the properties of the toxin-induced G1 arrest to see whether it resembled a Class I or Class II phenomenon.

We first monitored the effect of toxin on cell volume, as an indication of whether cell growth was continuing in arrested cells. Toxin-treated cells clearly showed a significant increase in relative volume compared with control cultures (Fig. 7), the mean volume of unbudded (G1) cells in the treated population increasing by $50 \%$ over $8 \mathrm{~h}$. Mother cells (i.e. the small proportion of budded cells in a treated population) also increased somewhat in volume. In normal yeast populations, the mean volume of the daughter cell at septation is around

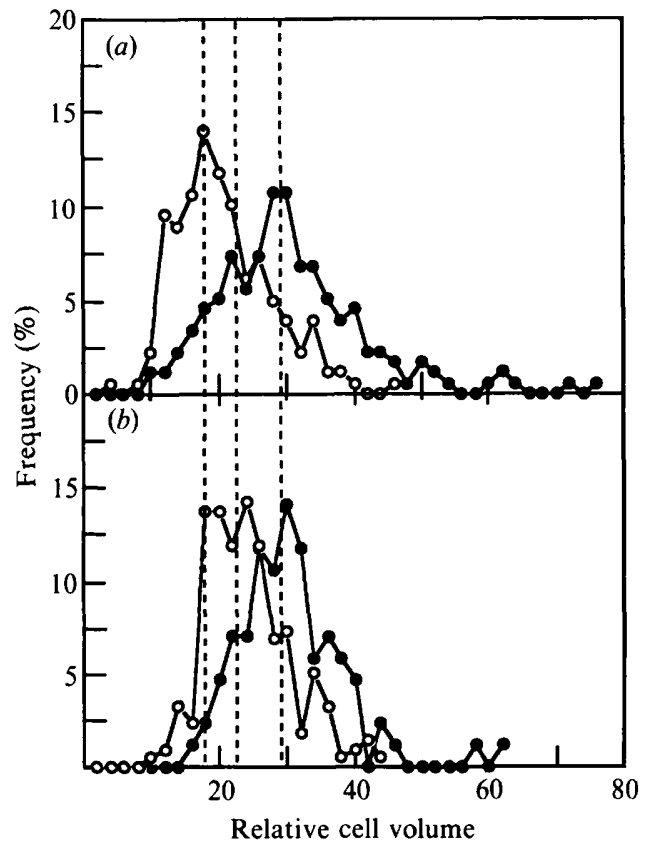

Fig. 7. Effect of $K$. lactis toxin on cell volume. The relative cell volume of individual unbudded $(a)$ and budded $(b)$ cells in control $(O)$ and toxin-treated $(O)$ cultures of LL20 was determined $8 \mathrm{~h}$ after addition of toxin $\left(5 \mathrm{ng} \mathrm{ml}^{-1}\right)$ to the latter and plotted as size distributions. The dotted lines (left to right) indicate the modal size of control unbudded, control budded and toxin-treated (budded or unbudded) cells respectively. Similar results were obtained when treated and untreated cell populations were analysed by FACS analysis (not shown).

$70 \%$ that of the mother cell (Hartwell \& Unger, 1977), as seen in Fig. 7. However, toxin treatment appeared to abolish this difference, since the mean volumes of toxintreated mother and unbudded cells became identical. We conclude that toxin-arrested cells can continue to increase in volume and are therefore not blocked for cell growth.

We next measured the ability of toxin-arrested cells to mate using a quantitative mating procedure. In these experiments, we used as the mating partner a strain carrying a dominant, toxin-resistant mutation in a gene required for the intracellular action of toxin (Butler $e t$ al., $1991 b$ ) so that matings could be performed in the continued presence of toxin but such that any diploids formed should be toxin-resistant. Regardless of whether matings were performed in the absence or continued presence of toxin, toxin-arrested cells were incapable of conjugation to form diploid cells (Table 2). Thus toxintreated cells arrest in G1 with neither a Class I nor a Class II phenotype. Such an effect is similar to that seen using the cell cycle mutations $c d c 65$ and $c d c 67$, two new Start mutations which permit continued cell growth and only partially inhibit macromolecular biosynthesis but 


\section{Table 2. Mating proficiency of toxin-treated cells}

Quantitative mating assays were performed as described (see Methods) on control and toxin-arrested cells of strain KY117 in either the presence or the absence of $K$. lactis toxin. In each case, the mating partner cells were either toxin-sensitive (LL20) or toxin-resistant derivatives of LL20 (ARB1, ARB15). For each partner strain, results are expressed relative to the matings performed with untreated KY117 cells in the absence of toxin (the absolute efficiency being given in brackets).

\begin{tabular}{|c|c|c|c|c|}
\hline \multirow[b]{4}{*}{ Mating strain } & \multicolumn{4}{|c|}{ Relative mating efficiency } \\
\hline & \multirow{2}{*}{\multicolumn{2}{|c|}{$\frac{\text { Toxin absent }}{\text { KY117 cells: }}$}} & \multirow{2}{*}{\multicolumn{2}{|c|}{$\begin{array}{l}\text { Toxin present } \\
\text { KY117 cells: }\end{array}$}} \\
\hline & & & & \\
\hline & Control & Arrested & Control & Arrested \\
\hline LL20 (w.t.) & $\begin{array}{l}100 \% \\
(25 \cdot 5)\end{array}$ & $0.02 \%$ & ND & ND \\
\hline $\begin{array}{l}\text { ARB1 } \\
\text { (recessive toxin') }\end{array}$ & $\begin{array}{l}100 \% \\
(15 \cdot 6)\end{array}$ & $0.05 \%$ & ND & ND \\
\hline $\begin{array}{l}\text { ARB } 15 \\
\left(\text { dominant toxin }{ }^{r}\right)\end{array}$ & $\begin{array}{r}100 \% \\
(4.4)\end{array}$ & $0.02 \%$ & $0 \cdot 14 \%$ & $0 \%$ \\
\hline
\end{tabular}

ND, not determined.

which abolish the mating proficiency of the arrested cells (Prendergast et al., 1990).

\section{Discussion}

$K$. lactis toxin causes an irreversible arrest of yeast cell proliferation in the unbudded (G1) phase of the cell cycle and arrested cells have an unreplicated DNA content. The action of toxin on cells is not immediate; rather it must be continuously present for over an hour before a significant proportion of the treated cells are affected. Progressively longer times of treatment lead to a G1 arrest and loss of cell viability, the latter continuing to decline after the increase in cell number ceases. This suggests that there is a finite time interval required for uptake or activation of the toxin by sensitive cells before it can exert its effects. When cells blocked in S-phase were treated with toxin and the S-phase block then removed, the majority of cells completed the current cycle and arrested in G1. Thus, even when the toxin has been present for sufficient time to overcome this latent period, most cells can nevertheless progress through the cell cycle until G1. In addition, arrested cells are not metabolically inactive. They continue to exclude vital stains such as methylene blue and Janus green for many hours (White et al., 1989) and in this work both protein and RNA synthesis continued after toxin administration, albeit at a reduced rate in the former case. Consistent with this, the volume of treated cells increases, suggesting that growth is continuing in the absence of division as occurs in a Class I Start arrest, such as that induced by mating pheromone treatment or growth of $c d c 28^{t s}$ strains at the nonpermissive temperature. However, unlike Class I arrest, toxin treatment abolishes mating proficiency.

In principle, since $\mathrm{G} 1$ is the major expandable portion of the cell cycle (Hartwell and Unger, 1977) it might be possible to account for the effect of the toxin by proposing that it acts as a progressive inhibitor of a continuous process required for growth rather than division, increasing the proportion of unbudded cells as the growth rate slowed. However, when growth is slowed, the size of the daughter cell at septation is reduced, owing to decreased capacity for growth during the budded proportion of the cell cycle, which remains relatively constant and independent of the culture doubling time (Hartwell \& Unger, 1977). This would have the effect of shifting the size distribution of unbudded cells in a population to lower values. However, the size distribution of toxin-treated unbudded cells clearly showed the opposite trend, inconsistent with such an effect. Nevertheless, several lines of evidence point to the toxin affecting continuous (or post-G1) processes. When S-phase arrested cells were treated with toxin and the S-phase block released, there was a slow increase in cell numbers over several hours such that the majority of cells completed the current cycle and arrested in G1. That progression to Gl arrest was so slow strongly suggests that in cells committed to a division cycle some other process, inhibited by toxin, is nevertheless limiting. Furthermore, treatment of cells with increasing concentrations of toxin reduced the synchrony of arrest, suggesting that an increasing proportion of budded cells are unable to reach $\mathrm{G} 1$ under these harsher conditions. Finally, even when cell number no longer increased, further and progressive loss of cell viability was seen, suggesting that the loss of viability was a secondary effect of the toxin.

These data may be explained by any of several models, some of which overlap: (i) toxin inhibits growth and not division, but causes a Gl arrest due to the kinetics of its action; (ii) toxin inhibits a process required for $\mathrm{Gl}$ and a second, continuous process which is less sensitive to the toxin; (iii) the putative second process is stage-specific, but acts after Gl (and the hydroxyurea block); (iv) and $\mathrm{G} 1$ and second processes are one and the same, but the requirement for the process in $\mathrm{Gl}$ is more stringent. A precedent for model (iv) is provided by prt $l^{\text {ts }}$ mutations. $P R T 1$ encodes a protein synthesis initiation factor (Keierleber et al., 1986) and prt $t^{t s}$ mutations which arrest in G1 at Start by use of 'intermediate' nonpermissive temperatures, cause an asynchronous arrest at higher temperatures (Hanic-Joyce et al., 1987). In the former case, mating competence of arrested cells is observed but 
in the latter instance it is lost. Thus relatively mild dysfunction of the PRT1 protein has a specific effect at $\mathrm{G} 1$ and has only a moderate effect on protein biosynthesis, possibly by differential effects on specific proteins needed for completion of Start (Hanic-Joyce et al., 1987), while more severe loss of function causes greatly reduced rates of protein biosynthesis and a generalized growth defect which is manifest as an asynchronous arrest of division.

While some of our data support model (i), the effect of toxin on cell volume is inconsistent with growth inhibition alone mediating the effects of the toxin (above). Regarding the other possibilities, it is impossible to distinguish between them on the basis of available information. While our data are consistent with a model where the toxin causes relatively mild inhibition of protein synthesis in the manner of the prtl mutations, proof for such a model will require much more detailed work. We hope that the characterization of $S$. cerevisiae mutants which are resistant to the toxin (Butler et al., $1991 b$ ) will shed more light on the molecular mechanisms of its action.

Thanks are due to Michael Kerr, Bob Potts and Kevin Crawford for assistance with flow cytometry, and to George Sprague, Howard Riezman and Tom Stevens for strains. This work was supported by an MRC grant (to M.J.R.S.) and an SERC Research Studentship (to J.H.W.)

\section{References}

Achstetter, T., Emter, O., Ehmann, C. \& Wolf, D. H. (1984). Proteolysis in eukaryotic cells. Identification of multiple proteolytic enzymes in yeast. Journal of Biological Chemistry 259, 13334-13343.

Banta, L. M., Robinson, J. S., Klionsky, D. J. \& EMr, S. D. (1988). Organelle assembly in yeast: characterisation of yeast mutants defective in vacuolar biogenesis and protein sorting. Journal of Cell Biology 107, 1369-1383.

BRADFORD, M. M. (1976). A rapid and sensitive method for the quantitation of microgram quantities of protein utilising the principle of protein-dye binding. Analytical Biochemistry 72, 248254.

Butler, A. R., O'Donnell, R., Martin, V. J., Gooday, G. W. \& STARK, M. J. R. (1991 a). Kluyveromyces lactis toxin has an essential chitinase activity. European Journal of Biochemistry (in the Press).

Butler, A. R., Porter, M. \& Stark, M. J. R. (1991 $b$ ). Intracellular expression of Kluyveromyces lactis toxin $\gamma$ subunit mimics treatment with exogenous toxin and distinguishes two classes of toxin-resistant mutant. Yeast 7 (in the Press).
ChAN, R. K. \& OTTE, C. A. (1982). Isolation and genetic analysis of Saccharomyces cerevisiae mutants supersensitive to Gl arrest by afactor and $\alpha$-factor pheromones. Molecular and Cellular Biology 2 , 11-20.

DUTCHER, S. K. \& HARTWELL, L. H. (1982). The role of S. cerevisiae cell division cycle genes in nuclear fusion. Genetics 100, 175-184.

Hanic-Joyce, P. J., Johnston, G. C. \& Singer, R. A. (1987). Regulated arrest of cell proliferation mediated by yeast prt I mutations. Experimental Cell Research 172, 134-145.

HaRTWELl, L. H. \& Unger, M. W. (1977). Unequal division in Saccharomyces cerevisiae and its implications for the control of cell division. Journal of Cell Biology 75, 422-435.

Hereford, L. M. \& Hartwell, L. H. (1974). Sequential gene function in the initiation of Saccharomyces cerevisiae DNA synthesis. Journal of Molecular Biology 84, 445-461.

HUTTER, K.-J. \& EIPEL, H. E. (1979). Microbial determinations by flow cytometry. Journal of General Microbiology 113, 369-375.

Keierleber, C., Wittekind, M., Qin, S. \& Mclaughllin, C. S. (1986). Isolation and characterisation of $P R T I$, a gene required for the initiation of protein biosynthesis in Saccharomyces cerevisiae. Molecular and Cellular Biology 6, 4419-4424.

Prendergast, J. A., Murray, L. E., Rowley, A., Carruthers, D. R., Singer, R. A. \& Johnston, G. C. (1990). Size selection identifies new genes that regulate Saccharomyces cerevisiae cell proliferation. Genetics 124, 81-90.

Robinson, J. S., Klionsky, D. J., BANTA, L. M. \& Emr, S. D. (1988). Protein sorting in Saccharomyces cerevisiae: isolation of mutants defective in the delivery and processing of multiple vacuolar hydrolases. Molecular and Cellular Biology 8, 4936-4948.

Romanos, M. A. \& BoYD, A. (1988). A transcriptional barrier to expression of cloned toxin genes of the linear plasmid $\mathrm{kl}$ of Kluyveromyces lactis: evidence that native $\mathrm{k} 1$ has novel promoters. Nucleic Acids Research 16, 7333-7350.

Rothman, J. H. \& Stevens, T. H. (1986). Protein sorting in yeast: mutants defective in vacuole biogenesis mislocalise vacuolar proteins into the late secretory pathway. Cell 47, 1041-1051.

Sherman, F., Fink, G. R. \& Hicks, J. B. (1986). Methods in Yeast Genetics. Cold Spring Harbor, NY: Cold Spring Harbor Laboratory.

Slater, M. L. (1983). Effect of reversible inhibition of deoxyribonucleic acid synthesis on the yeast cell cycle. Journal of Bacteriology 113, 263-270.

Stark, M. J. R., Boyd, A., Mileham, A. J. \& Romanos, M. A. (1990). The plasmid-encoded killer system of Kluyveromyces lactis: a review. Yeast 6, 1-29.

Sugisaki, Y., Gunge, N., Sakaguchi, K., Yamasaki, M. \& Tamura, G. (1983). Kluyveromyces lactis killer toxin inhibits adenylate cyclase of sensitive yeast cells. Nature, London 304, 464-466.

Sugisaki, Y., Gunge, N., SaKaguchi, K., Yamasaki, M. \& Tamura, G. (1984). Characterisation of a novel killer toxin encoded by a double-stranded linear DNA plasmid of Kluyveromyces lactis. European Journal of Biochemistry 141, 241-245.

Tokunaga, M., Kawamura, A. \& Hishinuma, F. (1989). Expression of pGKL killer 28K subunit in Saccharomyces cerevisiae: identification of $28 \mathrm{~K}$ subunit as a killer protein. Nucleic Acids Research 17, $3435-3446$.

WhEALS, A. E. (1987). Biology of the cell cycle in yeasts. In The Yeasts, vol. 1, 2nd edn., pp. 283-390. Edited by A. Rose \& S. Harrison. London: Academic Press.

White, J. H., Butler, A. R. \& StaRK, M. J. R. (1989). Kluyveromyces lactis toxin does not inhibit yeast adenylyl cyclase. Nature, London 341, 666-668. 